\title{
FROM RELICT SALINE WETLANDS TO NEW ECOSYSTEMS: CHANGES IN BIRD ASSEMBLAGES
}

\author{
DE RELICTOS DE HUMEDALES SALINOS \\ A NUEVOS ECOSISTEMAS: \\ CAMBIOS EN LOS ENSAMBLES DE AVES
}

\author{
Pablo Germán Brandolin ${ }^{1,2}$ *, Pedro Gerardo BlendingeR ${ }^{1,3}$ \\ and Juan José CANTERO ${ }^{2,4,5}$
}

Summary.- In the Pampa ecoregion of South America, the replacement of semi-natural ecosystems by agroecosystems is a major cause of biodiversity decline. Agricultural intensification has led to the almost total disappearance of pristine wetland vegetation and the decline of bird assemblages. Relicts of saline wetlands and modified surrounding habitats were chosen to explore differences and similarities in the assemblage structure of birds inhabiting the habitat spectrum from natural relicts to new agricultural ecosystems, in central Argentina. The study area is in the Pampa region, in the sector known as Flat Inland Pampa. Specifically, it is located in Marcos Juárez department, southeastern Córdoba province, Argentina. We identified eight habitats with contrasting floristic compositions and structures and three bird count surveys were conducted during an annual cycle: January-February, July-August, and October 2013. Fixed-radius survey stations were established in each habitat. Sixty bird species, from 21 families, were recorded. The results in terms of species diversity and trophic guilds indicate that bird species assemblages are associated differentially with different vegetation communities. The highest values of bird richness and guild numbers were recorded in structurally complex natural vegetation environments. The structurally simpler habitats modified by human activities were poorer in their bird assemblages. We conclude that the promotion and conservation of the patchiness of the landscape of natural saline wetlands (mixed grassland-shrubland) as the main physiognomies of the vegetation should have high priority in future agendas for conserving the integrity and diversity of bird populations of the remaining natural habitats in the Pampa ecoregion.

Key words: agroecosystems, biodiversity, grassland birds, Pampa ecoregion, South America.

\section{CONICET}

2 Departamento Biología Agrícola, Facultad de Agronomía y Veterinaria, UNRC,

Ruta Nacional 36, Km. 601, 5804 Río Cuarto, Córdoba, Argentina.

3 Instituto de Ecología Regional, Universidad Nacional de Tucumán, CC 34, 4107 Yerba Buena,

Tucumán, Argentina.

4 Instituto Multidisciplinario de Biología Vegetal (CONICET-UNC), Córdoba.

5 Museo Botánico Córdoba (UNC).

* Corresponding author: p_brando@hotmail.com 
Resumen.-En la ecorregión Pampa de América del Sur, la sustitución de los ecosistemas seminaturales por agroecosistemas es una de las principales causas de pérdida de biodiversidad. La intensificación agrícola ha llevado a la casi total desaparición de la vegetación nativa de los humedales salinos y al declive de los ensambles de aves asociados. Se eligieron relictos de humedales salinos y sus hábitats circundantes modificados para explorar las diferencias y similitudes en la estructura de los ensambles de aves que habitan desde hábitats naturales relictos a nuevos ecosistemas agrícolas, en el centro de Argentina. El área de estudio está incluida en la región Pampa, en la parte conocida como Pampa Interior Plana de América del Sur. Específicamente, el área se encuentra en el departamento Marcos Juárez, al sudeste de la provincia de Córdoba, Argentina. Se identificaron ocho hábitats con composiciones y estructuras florísticas muy contrastantes y se realizaron tres campañas de conteo de aves durante un ciclo anual: enero-febrero, julio-agosto y octubre de 2013. En cada uno de los hábitats se establecieron estaciones de conteo de aves de radio fijo. Se registraron 60 especies de aves en total pertenecientes a 21 familias. Los resultados en términos de diversidad de especies y gremios tróficos indican que las especies de los ensambles de aves se asocian diferencialmente con diferentes comunidades de vegetación. Los valores más altos de los números de la riqueza y de los gremios de aves fueron registrados en los ambientes naturales de vegetación estructuralmente complejos. Los hábitats más modificados por actividades humanas (estructuralmente más simples) fueron más pobres en sus ensambles de aves. Llegamos a la conclusión de que la promoción y conservación de los parches de paisaje de los humedales salinos naturales (mezcla de pastizales y matorrales) como la fisonomía principal de la vegetación debería tener una alta prioridad en las agendas futuras destinadas a la conservación de la integridad y la diversidad de las poblaciones de aves de los pocos hábitats naturales remanentes de la ecorregión Pampa.

Palabras clave: agroecosistemas, América del Sur, aves de pastizales, biodiversidad, ecorregión Pampa.

\section{INTRODUCTION}

One third of the potentially exploitable area worldwide has been converted to agriculture (Ormerod and Watkinson, 2000). Conversion of natural landscapes to agroecosystems and the consequent habitat simplification and loss are the main negative effects of agriculture on wildlife. Such habitat loss has a direct effect on biodiversity (Lacher et al., 1998), with birds being one of the most sensitive groups to land-use changes (Schawb et al., 2006). Agricultural intensification and land-use changes have deeply modified the complexity of bird habitats across all agricultural systems worldwide (Cerezo et al., 2011) and both factors are regarded as the major causes of the declines of grassland bird populations (Shutler et al., 2000; With et al., 2008; Azpiroz and Blake, 2009; Cerezo et al., 2011). Because land-use intensification is widespread and can affect large areas, its in- fluence on biodiversity is of great conservation and research interest.

At the global scale, several once common grassland bird populations have rapidly declined or undergone range-reduction, with all the evidence indicating that these declines are associated with intensified agricultural production (Fuller et al., 1995; Shi et al., 1999; Renfrew and Ribic, 2001; Vickery et al., 2001). The natural vegetation of the Pampas was originally a tall grass-steppe dominated by grasses such as Stipa, Piptochaetium, Aristida, Bromus and Poa, intermingled with prairies, marshes and edaphic communities (Soriano et al., 1991). At present, agricultural activity has caused profound degradation and replacement of the original environments and has increased the fragmentation of wetlands and grasslands (Quirós et al., 2002; Brandolin et al., 2013). Degradation of natural habitats as a consequence of expansion of the agricultural frontier has led to the almost complete disappearance 
of pristine grasslands and natural wetlands (De la Fuente and Suárez, 2008; Brandolin et al., 2013). In Argentina, for example, the cropland area in the Pampa region increased by $45 \%$ between 1990 and 2006, mostly cultivated with transgenic soybean (Vigglizzo et al., 2006; Gavier-Pizarro et al., 2012).

Relicts of natural vegetation of the Pampa region remain only in refuges, embankments and areas surrounding railroads, or in landscapes unsuitable for agriculture, such as saline wetlands and areas that flood (Soriano et al., 1991; Cantero et al., 2013). These relicts provide an opportunity to evaluate the effects of diversity loss due to land use changes (Isacch et al., 2003) and to contribute to the conservation of similar habitats that are threatened by such transformations. Although the ecology and conservation of some birds in South America (e.g. in temperate grasslands) have received special attention in the last decade (Azpiroz and Blake, 2009; Cerezo et al., 2011; Codesido et al., 2013), birds from Pampa saline wetlands were not included in the design of regional management and conservation strategies (Di Giácomo and Krapovickas, 2005).

Assemblages of terrestrial birds are closely related to the structural and floristic characteristics of the vegetation (Graham and Blake, 2001; Naugle et al., 2001; Skowno and Bond, 2003; Wakeley et al., 2007; Di Giácomo and López de Casenave, 2010) and to landscape characteristics (Isacch and Martínez, 2001; Polis et al., 2004; Fharig et al., 2010). At the same time, increased habitat complexity; defined as the horizontal, vertical and qualitative variation of the physical and biotic elements present, generates greater resources for birds, thus allowing the persistence of a greater number of species and guilds than in less complex habitats (MacArthur and McArthur, 1961; Tews et al., 2004; Codesido et al., 2013).

Birds play a vital role in maintaining ecological system stability and are a good indicator of environmental change in wetland ecosystems (Yuan et al, 2014). Birds are among the most iconic of ecological assets and very sen- sitive to changes of the surrounding habitat (Devictor and Jiguet, 2007; Wu et al., 2011). Although there is descriptive information on some ecological aspects of the avifauna associated with wetlands or temperate grasslands in South America: relating to abundance, diversity patterns, occupancy patterns, nesting and conservation (Azpiroz and Blake, 2009; Cozziani and Zalba, 2009; Cerezo et al., 2011), habitat use and habitat selection are poorly known (but see Di Giácomo and López de Casenave, 2010; Codesido et al., 2012). In general, at a local scale, the focus has been on the impact of within-habitat factors on bird populations (Soderstrom et al., 2001; Newton, 2004; Hendrickx et al., 2009), while, at a broader scale, land-use variables and the structure and composition of landscape have been investigated theoretically (Wretenberg et al., 2010; Cerezo et al., 2011; Hanspach et al., 2011). Furthermore, there are no comparative studies across the whole gradient of vegetational structure, from natural environments (grasslands-shrublands) to agricultural crops. Here our main objective is to fill this gap by identifying differences and similarities in the assemblage structure of birds inhabiting relicts of saline wetlands and environments transformed by agriculture in the South American Pampa.

We expected that (1) Bird richness and diversity in habitats would be greatest at the lowest levels of land-use intensity, i.e. higher in seminatural lands with native plant communities than in croplands highly modified by agriculture; (2) Natural vegetation systems greater in structural heterogeneity -such as shrublands- should have greater bird richness and diversity than grasslands; and (3) Bird assemblages in habitats would vary with land use because the intensity and type of land use affects habitat characteristics. For this purpose, we surveyed for one year the avifauna of the different plant communities (habitats) in a landscape that represent the environmental heterogeneity of the region, ranging from pristine relicts of saline wetlands to highly modified environments. We analysed species 

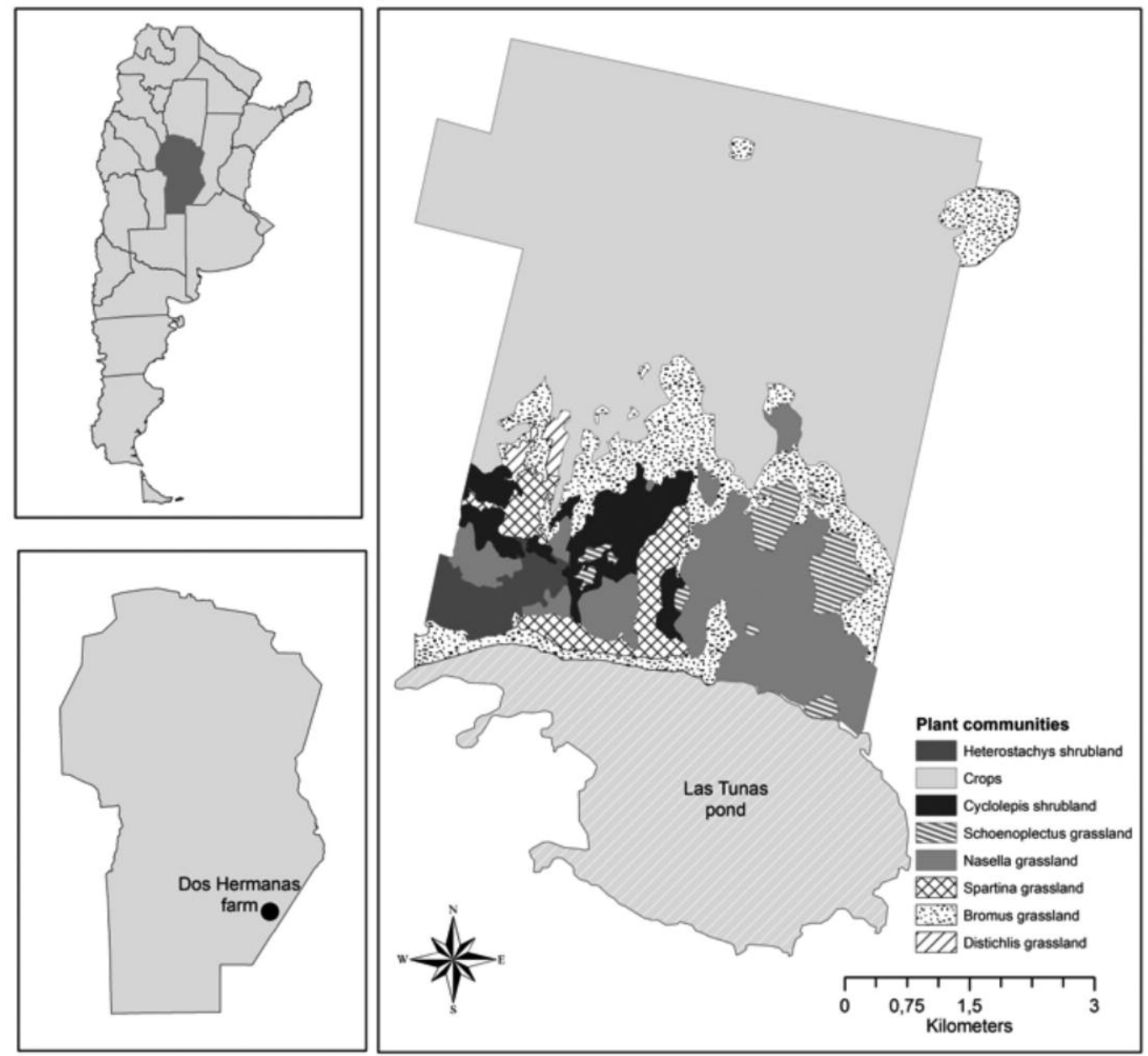

FIG. 1.-Location of Dos Hermanas farm in central Argentina and southeast of Cordoba province. [Ubicación de la Estancia Las Dos Hermanas en el centro de Argentina y sureste de la provincia de Córdoba.]

richness, diversity and trophic guilds, determined indicator species and evaluated the effects of landscape heterogeneity on bird assemblages in each plant community.

\section{MATERIAL AND METHODS}

\section{Study area}

The study area is in Marcos Juárez department, $12 \mathrm{~km}$ from the locality of Arias (33 $40^{\prime} \mathrm{S}$
/ 62 $31^{\prime}$ O), southeastern Córdoba province, Argentina (fig. 1). The area is within the Pampa region, specifically in the sector known as Flat Inland Pampa (Soriano et al., 1991). The climate is temperate, subhumid, with a mean annual rainfall of $725 \mathrm{~mm}$, presenting a socalled monsoon distribution, since most rainfall is concentrated in spring-summer (October-April) and the winters are dry. The mean annual temperature is $16^{\circ} \mathrm{C}$ (Cantero and León, 1999). The study was conducted at "Las Dos Hermanas" Farm (DHF), where livestock are 
raised on grassland plots and organic agriculture is conducted without use of fertilisers/biocides, following a strict integrated plan for soil and biodiversity conservation. DHF covers approximately 4,100 ha and the entire area is a Private Wildlife Reserve, with 1,005 ha devoted to the strict conservation of natural relicts of saline wetlands with natural grasslands and other natural vegetation systems (shrublands). DHF is an ideal farm for studying bird assemblages since the history of use and management are well documented and the diversity of agricultural production allows us to reconstruct the diversity of land uses in the Pampa region.

\section{Landscape and vegetation}

The relief in DHF is slightly undulating and associated with a depression, Las Tunas pond, with plant communities of contrasting structure and floristic composition closely associated with variations in use, relief, groundwater level and geochemistry (Cantero et al., 1996). We identified eight habitats for birds within DHF that represent a gradient in vegetation structure. This gradient results from land-use changes in the study region, from minimally used seminatural lands to intensively used agroecosystems where natural vegetation has been replaced by permanent cultivation (Cantero and León, 1999). The eight habitats were:

(1) Tall Nasella grassland (398 ha): tall, closed grassland located at the highest topographical positions: levees and sandy planoconvex hillocks. It has the greatest floristic diversity and structural complexity but is highly variable depending on grazing pressure and management history. The cover varies between $80-100 \%$ and vegetation is mainly composed principally of Nassella spp. in the high stratum. Eustachys retusa, Rhynchosia diversifolia, Bromus brevis, Pfaffia gnaphalioides and Berroa gnaphalioides are co-dominants in first stratum, Jarava plumosa, Digitaria californica,Hordeum stenostachys and Panicum bergii are found in the second stratum; and Nassella tenuissima and Nassella trichotoma occur in the third stratum. Some exotic weed species, including Cynodon dactylon, Viola arvensis and Carduus acanthoides, are present. The annual stocking rate is moderate (0.20 cattle/ha).

(2) Tall Spartina grassland (259 ha): tall, closed and homogenous grassland located in the most depressed sectors, with surface runoff of high salinity and is dominated by halophytic grassland principally of Spartina densiflora. The aspect and cover of this dominant species, with more than $90 \%$ of the cover-abundance, provide the stands with their typical aspect. Distichlis spicata, Symphyotrichum squamatum, Eleocharis macrostachya and Sarcocornia ambigua have high coverage values here. The annual stocking rate is low $(0.10$ cattle/ha).

(3) Tall Schoenoplectus grassland (109 ha): tall grassland, found in basins and ponds with superficial run-off as well as in areas with low salinity fluxes that are permanently flooded by the local groundwater. Schoenoplectus californicus is the dominant species in the most stands, sometimes sharing the dominance with Baccharis juncea and Typha latifolia, which generally form pure stands. The annual stocking rate is low ( 0.10 cattle/ha).

(4) Tall Cyclolepis shrubland (113 ha): occurs in very saline soils, on slopes of $0.2 \%$ and dominated by a low, deciduous shrubland of woody and succulent halophyte species. It has a complex structure with $40-70 \%$ cover of $C y$ clolepis genistoides and Atriplex undulata. This is closed shrubland up to $3 \mathrm{~m}$ high. Some cacti, such as Cereus, Opuntia and Trichocereus, may also be found within this community. Sarcocornia ambigua, with high coverage values is usually a co-dominant species at the lower stratum. Grazing by domestic herbivores is excluded.

(5) Low Heterostachys shrubland (169 ha): halophytic, sparse, short shrubland on highly saline soils and spatially very closely associated with the seasonally flooded margins of Las 
Tunas pond. There are two or three strata and plant cover is distinctively sparse, dominated by the highly salt tolerant halophytic shrub Heterostachys ritteriana and isolated shrubs of Atriplex undulata. Sarcocornia ambigua is also present here with high coverage values. The annual stocking rate is low ( 0.10 cattle/ha).

(6) Short Distichlis grassland (31 ha): short, closed or open grassland on slope below $0.2 \%$ with medium to slow runoff. The vegetation is characterised by low diversity and very simple structure (1-2 strata). Distichlis spicata is the dominant species, occurring in monospecific stands or co-dominant with Sarcocornia ambigua, Sporobolus pyramidatus and Plantago myosurus. The annual stocking rate is moderate (0.20 cattle/ha).

(7) Short Bromus grassland (493 ha): a short, closed grassland associated with planoconvex slopes with sharp microrelief. It occupies low hillsides, with slopes below $0.3 \%$. The vegetation includes some representatives of unit 1 (Nasella grassland) and is mainly characterised in cover and abundance by Bromus catharticus . Cynodon dactylon, Ambrosia tenuifolia, Setaria parviflora, Ammi majus, Hordeum stenostachys, Conyza bonariensis, Senecio pampeanus, Digitaria sanguinalis and Lolium multiflorum are the most constant species. The annual stocking rate is moderate $(0.20$ cattle/ha).

(8) Crops (Crops; 2311 ha): organic agricultural and cultivated pastures in a large area of slightly undulating relief and medium to low slopes. The original vegetation has been replaced by cereal and legume monocultures at the sites of highest relief and by perennial pastures on the lowest plots.

\section{Bird counts}

Three bird counts were conducted during an annual cycle in 2013: January-February (57 points counts), July-August (44 points counts), and October (54 points counts). Sampling units consisted of the eight habitats described above, where fixed-radius survey stations were es- tablished. This method involves moving to a predetermined location and recording all the birds identified within a fixed radius distance during a given period (Bibby et al., 2000). Based on previous sampling, we used a 100-m radius as the distance within which birds were identified and five-minute periods during which the observer counted once each individual bird detected by vision or sound. Birds clearly outside the habitat in which the point was located or that flew past the station and did not use the sampling area were excluded. Counts were made during the first four hours after sunrise and the order in which the stations were surveyed changed randomly. Sampling was not performed under strong wind or rain conditions (Ralph et al., 1995). The count points were randomly distributed within each habitat using a digital map (ArcMap 10.1) that includes the type of vegetation within the farm (Cantero et al., unpublished data,1991). Each count points were separated by a minimum distance of $200 \mathrm{~m}$ and not less than $200 \mathrm{~m}$ from an adjacent habitat or wire fence. Thus, two to five stations per habitat were placed randomly according to the shape and area of the habitat patch. The distribution of sampling units per habitat is indicated in table 2 .

\section{Data analysis}

The species richness, mean relative abundance, diversity (Shannon diversity index) and evenness (Pielou's evenness index) of the bird assemblage in each habitat were calculated. To calculate such measures we used the total sample obtained from three counts. Species were classified according to their migratory status (after Cueto et al., 2008) as: (1) "Migrant from the Temperate-Tropical system", nesting in the study area and moving to humid tropical latitudes to spend the austral winter; and (2) "Migrants from the Cold-Temperate system", nesting in cold regions from south and central Argentina and spending the austral winter in the north of the country. We 
added category (3) "Nearctic Migrant", species that nest in the northern hemisphere and migrate to the southern hemisphere in the austral summer. Species that do not perform any migratory movements in the region were classed as "residents". Species were also classified into four categories according to the main habitat used (following Vickery et al., 1999): obligate grassland species, facultative grassland species, aquatic species or forest species.

Rarefaction curves based on Monte Carlo simulations were made to compare bird richness among habitats (Gotelli and Entsminger, 2006).This allows comparison of the number of species expected per site, based on the lowest number of individuals recorded among the sites being compared.

Species with only one individual recorded were discarded from all statistical analyses. The ecological characteristics of foraging locations (aquatic, grassland, upper canopy, shrub layer and ground) and food type (insects, other invertebrates, seeds, leaves and generalist; see supplementary electronic material, appendix 1) were subjected to a hierarchical cluster analysis using Jaccard's similarity index with arithmetic group averages. The cluster of species similarities was depicted in a dendrogram to determine bird guilds grouped by main food type and foraging location, on the basis of relative similarity. We used this guild classification to compare bird assemblage structure among individual habitats using the bird guild diversity (Shannon diversity index).

To evaluate the association of specific bird assemblages with habitats, we applied a nonmetric multi-dimensional scaling (MDS) approach (McCune and Grace, 2002). The contribution of each bird species in the twodimensional plot was determined by an analysis of dissimilarity using the SIMPER routine (Clarke and Gorley, 2001). To represent within-habitat variation in bird species assemblages we analysed data using the mean abundance of each bird species as the response variable and the season (summer, winter, spring) as the repeated measure for each habitat type. We used $\mathrm{P}<0.01$ as the level of significance. Plant species with only one individual were discarded and mean abundance values were relativised. We then performed a one-way analysis of similarity using the Bray-Curtis similarity index to test the hypothesis that avian assemblages differ between sites other than by chance (ANOSIM; Clarke and Warwick, 1994). The mean abundance data were used, after standardisation, and test significance was determined by comparison with values obtained using a Monte Carlo randomisation procedure. These statistical analyses were performed using the PRIMER software package (PRIMER software package; Clarke and Gorley, 2001).

Indicator species analysis was used to define the bird species characteristic of each habitat (Dufrene and Legendre, 1997; Graham and Blake, 2001). This method is based on the specificity and degree of fidelity of a species to a particular habitat and yields values ranging from 0 (no indication) to 100 (perfect indication). Bird species with high values are considered the best indicators for a particular habitat because they are more likely to be found in that habitat than other species. To check whether a species is indicative of more than one site, we repeated the analysis removing the plant community that was previously associated with a species. Only species with indicator values that were significant ( $\mathrm{p}<0.01$; Monte Carlo test; 4999 permutations) and $>20 \%$ are reported.

\section{RESULTS}

\section{General assemblage}

Sixty species belonging to 21 families were recorded: five species belonging to the ColdTemperate migratory system (sharp-billed canastero Asthenes pyrrholeuca, Austral negrito Lessonia rufa, gray-bellied shrike- 
tyrant Agriornis micropterus, lesser shriketyrant Agriornis murinus and white-banded mockingbird Mimus triurus); five species belonging to the Tropical-Temperate system (vermilion flycatcher Pyrocephalus rubinus, bearded tachuri Polystictus pectoralis, tropical kingbird Tyrannus melancholicus, forktailed flycatcher Tyrannus savana and whiterumped swallow Tachycineta leucorrhoa); and only one Nearctic migrant species (upland sandpiper Bartramia longicauda; see Supplementary Electronic Aaterial, appendix 1). Assemblage species composition showed that $56.6 \%$ of species were exclusive to grassland, with 16 being obligate and 18 facultative grassland species; 10 species were aquatic and the remaining 16 were forest species (see Supplementary Electronic Material, Appendix 1).

\section{Bird richness and abundance}

The rarefaction analysis differentiated two main groups of habitats with similar bird species richness values (fig. 2). The lowest values were recorded in Distichlis grassland, Crops, Bromus grassland, Schoenoplectus grassland and Spartina grassland; an intermediate value was obtained in Nasella grassland; and the highest values were recorded in Heterostachys shrubland and Cyclolepis shrubland (table 1). Slopes of accumulation curves of bird species achieve a slight stability level in the cumulative number of individuals for all habitats (fig. 2). Furthermore, the highest cumulative richness values of all the surveys corresponded to Cyclolepis shrubland ( $\mathrm{n}=30$ species) and Nasella grassland $(n=26)$, whereas the lowest ones corresponded

TABLE 1

Summary metric calculated for each habitat at Dos Hermanas Farm. Surveys (n), mean abundance (A), cumulative number of species $(\mathrm{S})$, Shannon diversity index $(\mathrm{H})$, evenness $(\mathrm{E})$, guild diversity $(\mathrm{GH})$, mean expected (ME) number of species (rarefaction with 1000 permutations; minimum Heterostachys shrubland $=75 ; \mathrm{CI}=95 \%$ confidence intervals).

[Resumen de los índices calculados para cada hábitat en la Estancia Las Dos Hermanas. Censos (n), abundancia promedio (A), riqueza acumulada de especies $(S)$, indice de diversidad de Shannon $(H)$, equitatividad $(E)$, diversidad de gremios $(G H)$, promedio esperado de especies $(M E)$ (rarefacción con 1000 permutaciones; valor mínimo arbustal de Heterostachys $=75$; IC = intervalo de confianza al 95\%).]

\begin{tabular}{cccccccc}
\hline Habitat & $\mathbf{n}$ & $\mathbf{A}$ & $\mathbf{S}$ & $\mathbf{H}$ & $\mathbf{E}$ & $\mathbf{G H}$ & ME $(\mathbf{C I})$ \\
\hline Distichlis grassland & 8 & 17.38 & 14 & 1.90 & 0.72 & 0.45 & $12.09(10-14)$ \\
\hline Crops & 25 & 5.92 & 16 & 2.16 & 0.78 & 1.07 & $13.11(11-15)$ \\
\hline Bromus grassland & 21 & 8.38 & 16 & 2.25 & 0.81 & 0.85 & $13.28(11-15)$ \\
\hline Schoenoplectus grassland & 9 & 15.78 & 17 & 2.05 & 0.73 & 0.88 & $13.68(11-16)$ \\
\hline Spartina grassland & 18 & 8.00 & 16 & 2.22 & 0.80 & 1.24 & $14.10(12-16)$ \\
\hline Nasella grassland & 41 & 6.05 & 26 & 2.56 & 0.79 & 1.26 & $17.79(14-21)$ \\
\hline Heterostachys shrubland & 10 & 7.50 & 19 & 2.36 & 0.80 & 1.09 & 19 \\
\hline Cyclolepis shrubland & 23 & 12.04 & 30 & 2.84 & 0.84 & 1.17 & $21.19(17-25)$ \\
\hline
\end{tabular}


to Distichlis grassland $(\mathrm{n}=14)$ and Spartina grassland, Crops and Bromus grassland ( $\mathrm{n}=16$ ) (fig. 2).

Mean bird abundance reached maximum values in Distichlis grassland and Schoenoplectus grassland and the minimum values were obtained in Crops (table 1). The species with highest mean abundance in all samples was the great pampa-finch (see supplementary electronic material, appendix 1). The highest diversity values were obtained in Cyclolepis shrubland and Nasella grassland $(\mathrm{H}=2.84$ and $\mathrm{H}=2.56$, respectively), with the minimum value obtained in Distichlis grassland $(H=1.9)$. Evenness was similar and high in all eight sites (0.72 [Distichlis grassland] $\leq \mathrm{E} \leq 0.84$ [Cyclolepis shrubland]) (table 1).

\section{Structure of trophic guilds}

Cluster analysis revealed nine groups at a distance of 0.65 (fig. 3). This cut-off level identifies nine internally coherent groups and separates groups of species with clearly different ecologies. These groups differed in terms of species-specific relationships with

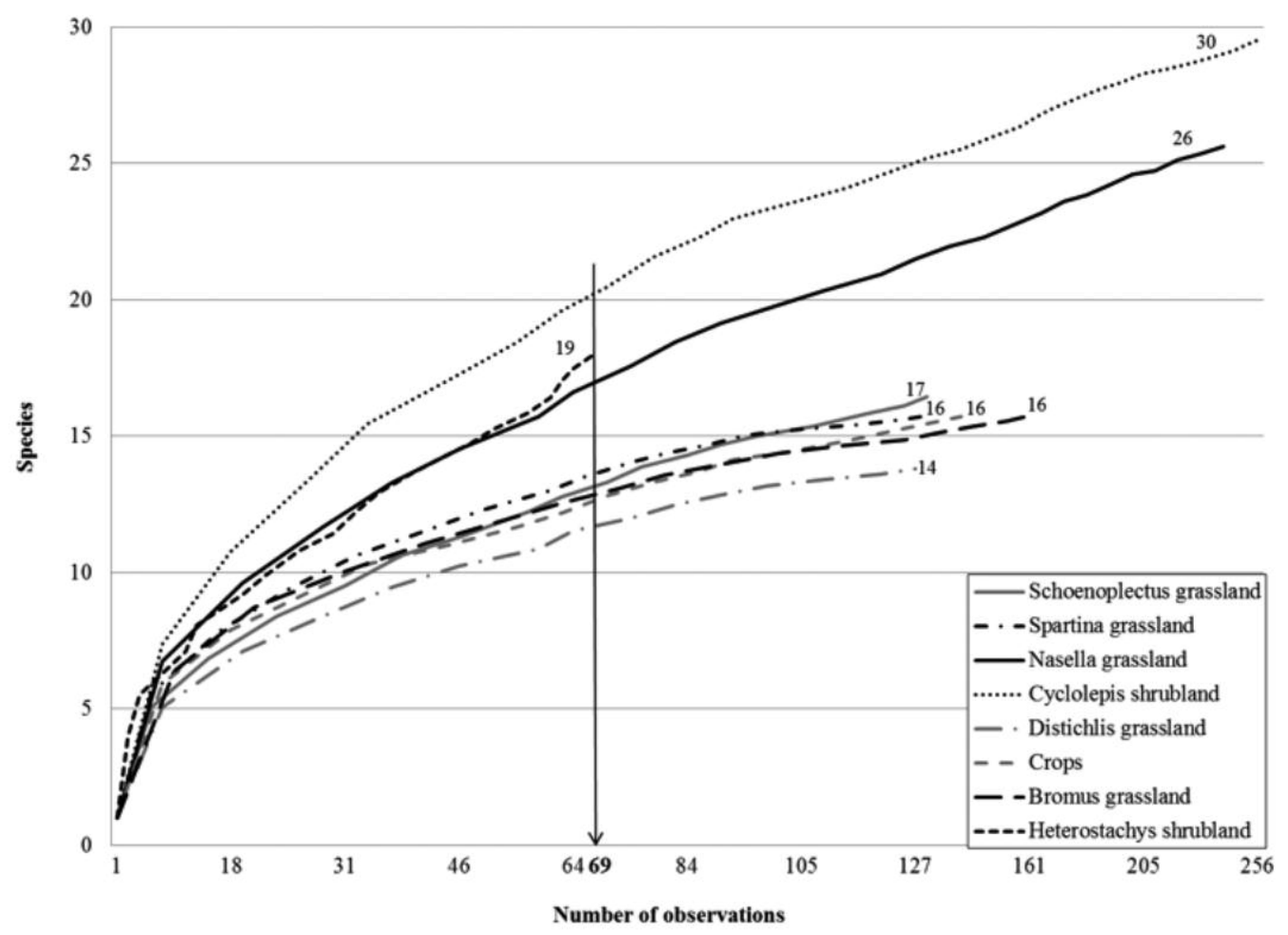

FIG. 2.- Rarefaction curves based on the number of individuals of bird assemblages in the eight habitats of Dos Hermanas Farm. The value of total richness for each habitat and the minimum number of individuals (Heterostachys shrubland) are indicated.

[Curvas de rarefacción basadas en el número de individuos de los ensambles de aves en los ocho hábitats de la Estancia Las Dos Hermanas. Se indica el valor de la riqueza total para cada hábitat y el número mínimo de individuos registrados (arbustal de Heterostachys).] 


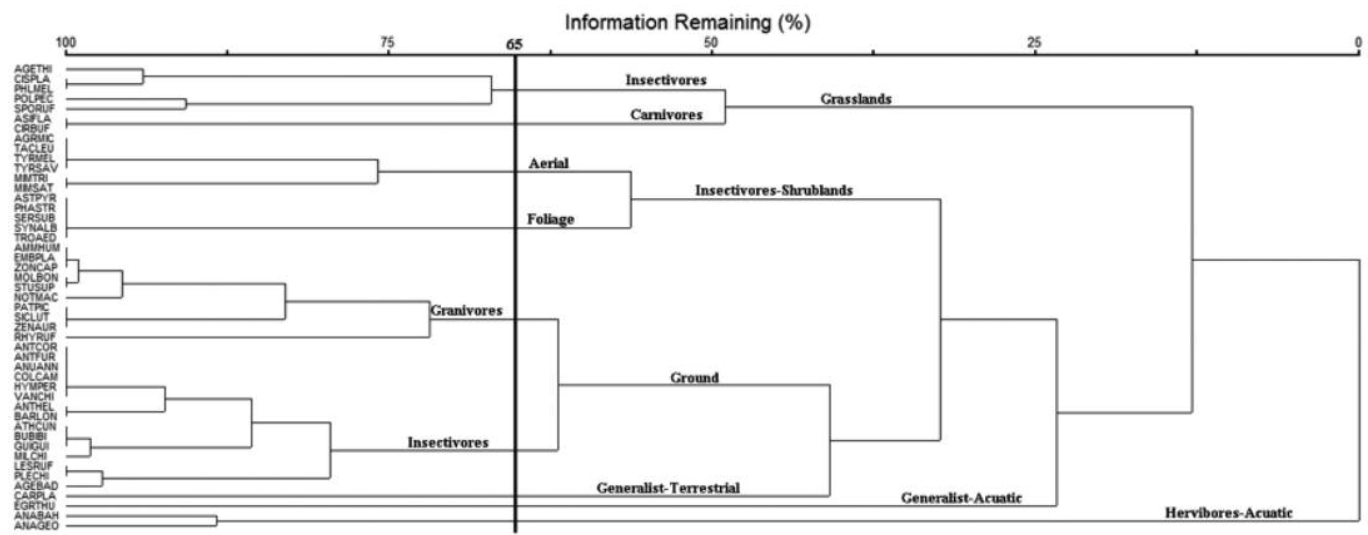

FIG. 3.-Cluster of multidimensional use (foraging location and food type) among the species of Dos Hermanas Farm. For species codes see Supplementary Electronic Material, Appendix 1.

[Agrupamiento multidimensional de usos (sitio de forrajeo y tipo de alimentos) entre las especies de la Estancia Las Dos Hermanas. Para los códigos de las especies véase el Apéndice 1 en el Material Electrónico Suplementario.]

foraging location and food type and grouped species with similar ecological requirements.

The grassland-insectivore guild was composed of five species while the grassland-carnivore guild includes only the short-eared owl Asio flammeus and long-winged harrier Circus buffoni. The bush-insectivore guild is composed of two smaller groups differentiated by foraging stratum (aerial vs. foliage) with six and five species respectively. The groundgranivore guild groups ten species. The ground-insectivore guild, with 15 species, was the most diverse. The guilds of terrestrialgeneralist species and aquatic-generalists each comprise a single species, the Southern caracara Caracara plancus and snowy egret Egretta thula respectively. These latter species are food type generalists but they differ in their foraging sites, the Southern caracara being mainly terrestrial and the snowy egret using aquatic environments. The aquatic-herbivore guild comprises two duck species that feed in aquatic environments or on floodplains.

The abundance of guilds by habitat highlights Nasella grassland with the greatest guild abundance ( $\mathrm{n}=7$ ), followed by the $C y$ clolepis shrubland $(\mathrm{n}=6)$. Schoenoplectus grassland, Spartina grassland, Distichlis grassland and Crops had 5 guilds and Bromus grassland and Heterostachys shrubland showed lower guild diversity with only 4 guilds. Guild richness was similar across the eight sites, but showed slight differences in diversity. The lowest values of guild diversity were in Distichlis grassland, Bromus grassland and Schoenoplectus grassland $(0.45,0.85$ and 0.88 respectively). The highest values were for Nasella grassland, Spartina grassland and Cyclolepis shrubland (1.24, 1.26 and 1.17). Crops and Heterostachys shrubland presented intermediate values (table 1).

\section{Bird composition}

The MDS analysis indicated that habitats were fitted to the first two ordination axes according to differences in diversity and abundance of bird species (Stress $=0.2$ ). Tall environments were differentiated from short ones 
Values of the significance levels of the ANOSIM analysis for bird assemblages among eight habitats at Dos Hermanas Farm. $\mathrm{P}<0.05$ are highlighted.

[Valores del nivel de significación del análisis ANOSIM para los ensambles de aves entre los ocho hábitats de la Estancia Las Dos Hermanas. Se indican los $P<0,05$.

\begin{tabular}{|c|c|c|c|c|c|c|c|}
\hline & 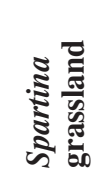 & 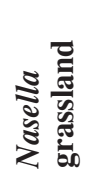 & 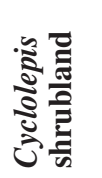 & 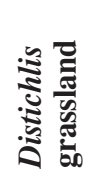 & 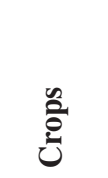 & 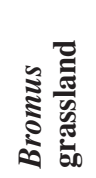 & 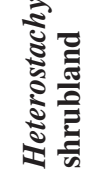 \\
\hline Schoenoplectus grassland & 0.647 & 0.954 & 0.001 & 0.004 & 0.001 & 0.727 & 0.001 \\
\hline Spartina grassland & & 0.572 & 0.001 & 0.004 & 0.001 & 0.002 & 0.1 \\
\hline Nasella grassland & & & 0.001 & 0.022 & 0.001 & 0.003 & 0.001 \\
\hline Cyclolepis shrubland & & & & 0.001 & 0.001 & 0.001 & 0.014 \\
\hline Distichlis grassland & & & & & 0.445 & 0.727 & 0.055 \\
\hline Crops & & & & & & 0.05 & 0.069 \\
\hline Bromus grassland & & & & & & & 0.265 \\
\hline
\end{tabular}

and crops. In turn, all grasslands were well differentiated from sites with woody vegetation (Cyclolepis shrubland and Heterostachys shrubland) (fig. 4). Crops were well differentiated from all other habitats. The similarity analysis revealed significant differences in the compositions of bird assemblages between habitats (ANOSIM, Global R $=0.171$, $\mathrm{P}<0.05)$. In paired comparisons, the greatest differences occurred between Cyclolepis shrubland, Distichlis grassland and Crops, which were significantly different from the remaining sites (table 2). The tall grasslands, in general, did not present significant differences between them (Schoenoplectus grassland $\approx$ Spartina grassland $\approx$ Nasella grassland), but differed from the remaining sites (except for Schoenoplectus grassland $\approx$ Bromus grassland and Nasella grassland $\approx$ Heterostachys shrubland). Bird species responded to changes in the structural complexity of habitats; species such as the Southern lapwing
Vanellus chilensis contributed to the high percentage assemblages of Crops, Heterostachys shrubland, Bromus grassland and Distichlis grassland. The white-browed blackbird Sturnella superciliaris also contributed significantly to the Crops assembly. The great pampa-finch Embernagra platensis was important to the Bromus grassland, Nasella grassland and Schoenoplectus grassland assemblages; and the sedge wren Cistothorus platensis contributed significantly to the Nasella grassland, Schoenoplectus grassland and Spartina grassland assemblages (table 3 ).

The indicator species analysis identified 11 species with significant indicator values ( $p<0.01$ and IV $>20 \%$ ) for six habitats. Five species were indicators for Cyclolepis shrubland, three species for Distichlis grassland, two species for Schoenoplectus grassland, four for Heterostachys shrubland and one for Nasella grassland and Spartina grassland. 
TABLE 3

Contribution of species to the average Bray-Curtis similarity between groups of samples (SIMPER analysis) at Dos Hermanas Farm. The average similarity for each habitat type is given in parentheses.

[Contribución de las especies al promedio de similitud de Bray-Curtis entre los grupos de muestras (análisis SIMPER) en la Estancia Las Dos Hermanas. Se indica entre paréntesis el promedio de similitud para cada tipo de hábitat.]

\begin{tabular}{|c|c|c|}
\hline & $\%$ contribution & $\begin{array}{l}\text { Cumulative } \\
\% \text { contribution }\end{array}$ \\
\hline \multicolumn{3}{|l|}{ Crops (27.92) } \\
\hline Vanellus chilensis & 40.35 & 40.35 \\
\hline Sturnella superciliaris & 35.23 & 75.58 \\
\hline Colaptes campestris & 12.8 & 88.38 \\
\hline Milvago chimango & 7.83 & 96.21 \\
\hline \multicolumn{3}{|l|}{ Heterostachys shrubland (29.62) } \\
\hline Vanellus chilensis & 41.37 & 41.37 \\
\hline Zonotrichia capensis & 29.84 & 71.21 \\
\hline Embernagra platensis & 18.76 & 89.97 \\
\hline Anumbius annumbi & 6.62 & 96.59 \\
\hline \multicolumn{3}{|l|}{ Bromus grassland (19.31) } \\
\hline Vanellus chilensis & 48.45 & 48.45 \\
\hline Embernagra platensis & 30.31 & 78.77 \\
\hline Anthus furcatus & 7,91 & 86.68 \\
\hline Sicalis luteola & 5.92 & 92.6 \\
\hline \multicolumn{3}{|l|}{ Distichlis grassland (5.22) } \\
\hline Vanellus chilensis & 83.33 & 83.33 \\
\hline Sicalis luteola & 16.67 & 100 \\
\hline \multicolumn{3}{|l|}{ Nasella grassland (48.98) } \\
\hline Cistothorus platensis & 32.55 & 32.55 \\
\hline Embernagra platensis & 19.43 & 51.98 \\
\hline Milvago chimango & 12.47 & 64.45 \\
\hline Sicalis luteola & 11.15 & 75.6 \\
\hline Nothura maculosa & 10.24 & 85.84 \\
\hline Circus buffoni & 3.76 & 89.61 \\
\hline Zonotrichia capensis & 2.85 & 92.46 \\
\hline \multicolumn{3}{|l|}{ Schoenoplectus grassland (25.09) } \\
\hline Sicalis luteola & 34.51 & 34.51 \\
\hline Embernagra platensis & 30.19 & 64.7 \\
\hline Cistothorus platensis & 27.17 & 91.87 \\
\hline \multicolumn{3}{|l|}{ Spartina grassland (42.02) } \\
\hline Cistothorus platensis & 61.89 & 61.89 \\
\hline Agelasticus thilius & 13.02 & 74.92 \\
\hline Embernagra platensis & 11.89 & 86.81 \\
\hline Sicalis luteola & 3.61 & 90.42 \\
\hline \multicolumn{3}{|l|}{ Cyclolepis shrubland (40.27) } \\
\hline Zonotrichia capensis & 21.66 & 21.66 \\
\hline Sicalis luteola & 20.88 & 42.54 \\
\hline Zenaida auriculata & 13.75 & 56.29 \\
\hline Patagioenas picazuro & 10.95 & 67.24 \\
\hline Embernagra platensis & 9.22 & 76.46 \\
\hline Mimus saturninus & 6.58 & 83.04 \\
\hline Phacellodomus striaticollis & 4.65 & 87.69 \\
\hline Cistothorus platensis & 4.45 & 92.15 \\
\hline
\end{tabular}




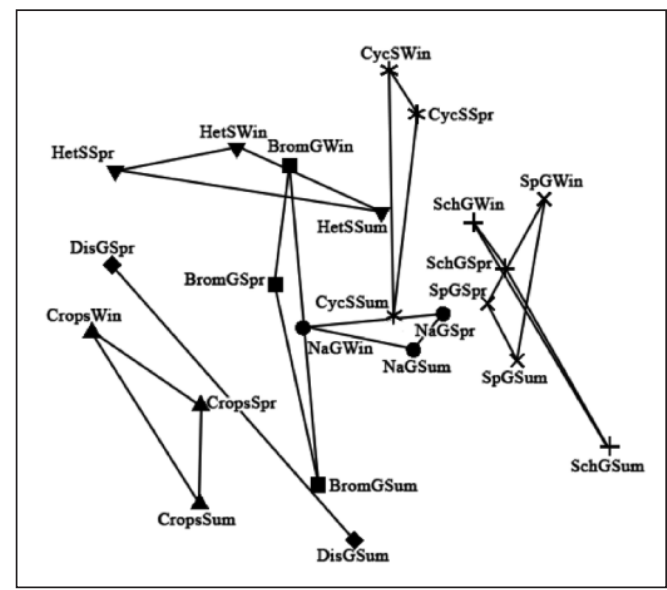

FIG. 4.-Ordination (NMS) based on the mean abundance of each bird species at Dos Hermanas Farm. Polygons group repeated measures in every season for each habitat. DisG: Distichlis grassland; BromG: Bromus grassland; SchG: Schoenoplectus grassland; SpG: Spartina grassland; NaG: Nasella grassland; HetS: Heterostachys shrubland; CycS: Cyclolepis shrubland.

[Ordenación (NMS) basada en el promedio de abundancia de cada especie de ave de la Estancia Las Dos Hermanas. Los polígonos agrupan medidas repetidas en cada estación para cada hábitat. DisG: pastizal de Distichlis; BromG: pastizal de Bromus; SchG: pastizal de Schoenoplectus; $S p G$ : pastizal de Spartina; NaG: pastizal de Nasella; HetS: arbustal de Heterostachys; CycS: arbustal de Cyclolepis.]

Four species were indicators for more than one habitat: the sedge wren Cistothorus platensis was an indicator of all tall grasslands (Schoenoplectus grassland, Spartina grassland and Nasella grassland), the sharp-billed canastero Asthenes pyrrholeuca and rufouscollared sparrow Zonotrichia capensis were indicators of the shrublands (Cyclolepis shrubland and Heterostachys shrubland) and the Southern lapwing Vanellus chilensis was an indicator of sites with open spaces and low vegetation (Distichlis grassland and Heterostachys shrubland) (table 4).

\section{DisCUSSION}

This study comprises the first analysis of relationships between the structure of bird assemblages and the structure of habitats in a highly heterogeneous region of Inland Pampa of South America, from relicts of natural halophilous shrublands and grasslands to agricultural systems. Since most original habitat in the Inland Pampa has been modified, our study had limited opportunity for replication, and the particular characteristics of the sites or newly modified ecosystems may have influenced our results in ways unconnected to the regional context. Although we cannot separate the effects of habitat and land use in the differences observed in bird assemblages, our findings are consistent with theoretical predictions that bird richness and diversity are higher in semi-natural lands with native plant communities than in areas highly modified by agriculture.

Our study shows a strong positive relationship between habitat structure and that of bird assemblages. The greatest diversity of birds and trophic guilds were related to most structurally complex habitat and structurally simple habitats were poorest in their bird assemblages. As shown in our results, bird assemblages are most similar in sites with similar physiognomic structures. In turn, some particular species had very marked affinities with respect to particular habitat types, indicating that certain local conditions of a site play an important role in determining the presence of individual species. For example, the sedge wren is almost exclusively found in grassland habitat, the sharp-billed canastero in shrublands and the Southern lapwing in low open habitat. These findings agree with the hypothesis that birds recognise different physiognomic vegetation types as unique habitats (Keith et al., 1997; Mazerolle and Villard, 1999), which can determine the composition of bird assemblages (Filloy et al., 2010; Cerezo et al., 2011) and the trophic guilds present. 


\section{TABLE 4}

Bird species observed at Dos Hermanas Farm with significant indicator values.

[Resumen de las especies de aves observadas en la Estancia Las Dos Hermanas con un valor indicador significativo.]

\begin{tabular}{lcccc}
\hline \multicolumn{1}{c}{ Species } & $\begin{array}{c}\text { Species } \\
\text { code }\end{array}$ & $\begin{array}{c}\text { Indicator } \\
\text { value }\end{array}$ & P & Indicated habitat \\
\hline Patagioenas picazuro & PATPIC & 31.7 & 0.0004 & Cyclolepis shrubland \\
Asthenes pyrrholeuca & ASTPYR & 22.9 & 0.0042 & Cyclolepis shrubland \\
Zonotrichia capensis & ZONCAP & 25.9 & 0.0042 & Cyclolepis shrubland \\
Zenaida auriculata & ZENAUR & 38.5 & 0.001 & Cyclolepis shrubland \\
\hline Phacellodomus striaticollis & PHASTR & 20.3 & 0.009 & Cyclolepis shrubland \\
Embernagra platensis & EMBPLA & 40.9 & 0.0006 & Schoenoplectus grassland \\
\hline Cistothorus platensis & CISPLA & 29.4 & 0.001 & Schoenoplectus grassland \\
& & 32 & 0.0024 & Spartina grassland \\
Bubulcus ibis & & 0.0012 & Heterostachys shrubland \\
Anthus hellmayri & BUBIBI & 24.7 & 0.0018 & Distichlis grassland \\
Vanellus chilensis & ANTHEL & 25.6 & 0.0036 & Distichlis grassland \\
\hline Lessonia rufa & VANCHI & 24.6 & 0.006 & Distichlis grassland \\
\hline
\end{tabular}

The Pampa landscape has undergone almost total transformation due to intensive agriculture and human settlement (Soriano et al., 1991). It is thus important and a priority to collect ecological data from the few remaining relict habitats of this threatened region. The relationships between birds and vegetational structure have been intensely debated in recent years (Graham and Blake, 2001; Naugle et al., 2001; Skowno and Bond, 2003; Wakeley et al., 2007; Di Giácomo and López de Casenave, 2010). Previous work on the Pampa avifauna (e.g. Isacch et al., 2003; Filloy and Bellocq, 2007; Cerezo et al., 2011; Di Giácomo and López de Casenave, 2010) did not include relict environments in pristine condition.
To our knowledge, this is the first systematic study of birds that includes relicts of saline wetlands in an excellent state of conservation within the Inland Pampa region. Di Giácomo and López de Casenave (2010) studied birds near DHF, in an area with highly human-disturbed environments and homogenisation of vegetation due to agricultural activities, and recorded lower species-richness (41) than in the present work. Codesido et al. (2008) also analysed bird assemblages of the Inland Pampa region but recorded lower species richness (43 in summer and 30 in winter) than in the present work. The lower species-richness recorded by these studies could reflect that they considered crops and 
edges of pastures, but not natural relicts, and because the agricultural systems involved were non-organic, unlike DHF. This difference suggests a greater richness/area relationship between Pampa grasslands in good condition, such as those at DHF, than in modified ones, which can be explained by the greater structural complexity of natural vegetation. The relicts of natural grasslands in the Pampa probably have an island-like effect within the surrounding agricultural matrix, being selected by birds in preference to completely agricultural environments lacking suitable habitats (e.g. Carrascal and Tellería, 1988).

The component plant communities, which are closely associated with the structure of the landscape, reveal a highly patchy spatial pattern, with low alpha and high beta plant diversity (Whittaker et al., 2001). The Pampa grasslands, although floristically poor compared with other ecoregions (Bilenca and Miñaro, 2004), are heterogeneous and structurally complex. The spatial coexistence of contrasting physiognomies of vegetation (e.g. grassland-shrubland), either from natural biotic and abiotic conditions or as a result of human-associated activities such as grazing, generates high values in the total diversity of the landscape and has a positive effect on the diversity of bird assemblages in the Inland Pampa region.

In general, natural and slightly modified habitats in the Pampa are more frequently used by birds than highly modified habitats (Codesido et al., 2008; Filloy et al., 2010; Isacch and Cardoni, 2011; Agra et al., 2015; Azpiroz and Blake, 2016). On the other hand, landscape disturbances that increase structural complexity and plant diversity promote greater bird species richness (Isacch et al., 2003). For example, Weyland et al. (2014) recognised that the natural process of shrub encroachment in the Rolling Pampa region may be one of the important factors in determining the distribution of bird species. In this work, we found an association between the values of bird diversity and changes in the vegetation. These changes may be related to natural ecological processes, such as the shrub encroachment into grassland or to human activities like grazing or replacement of vegetation by crops.

Similarly to what happens at the interspecific level, this study shows that the diversity of trophic guilds declines with the simplification of habitat structure. Structure of vegetation can influence the supply of resources and might be related to variation in guild composition. We find that trophic guilds show similar variation in diversity between habitats than species richness, the most common measure of biodiversity used by scientists, conservationists and policy makers (Flynn et al., 2009). This enlightens the usefulness of trophic guilds to provide an integrated and concise framework for linking responses of bird assemblages to environmental changes (Petchey et al., 2007; Dray and Legendre, 2008) mainly in disturbed man-managed ecosystems (Azeria et al., 2011). These changes in ecological community structure result in a decrease in functional diversity that is always associated with consequences for ecosystem function (Luck et al., 2013).

The study of the relationship between the distribution of organisms and landscape structure is a fundamental issue in community ecology; having sufficient knowledge of this subject is the basis for generating appropriate proposals for the conservation of diversity (Cody, 1985; Petit et al., 1995; Margules and Pressey, 2000; Cueto et al., 2006). The conservation of bird populations depends on habitat protection at an appropriate scale to the group or species that are the target of conservation (Petit et al., 1995). Management efforts focused on restoring ecological functions and natural vegetation structure would ensure the presence of birds in these environments (Fletcher and Koford, 2002) and, conversely, landscape alterations that simplify the complexity of environments or drastically modify the original physiognomy of the grasslands 
would negatively affect bird assemblages. In environments such as those in DHF it is essential to maintain and promote landscape heterogeneity, preserving the original grassland-shrubland features of the region to conserve the integrity and diversity of bird populations.

The Dos Hermanas Farm, especially its strict conservation area, is considered one of the last relicts of the original environments of Inland Pampa that remains in excellent condition. Therefore, it is essential that conservation policy makers, at both local and regional scales, assess the potential importance and compatibility of certain land uses with the conservation of biodiversity (Petit et al., 1995). Contamination by fertilisers, pesticides and animal residues, as well as the loss of biodiversity, are regarded as the main environmental problems associated with agricultural activity (Oesterheld, 2008). In addition, in view of the growing trend of agricultural expansion into natural environments in Argentina and worldwide, there is an urgent need for change. Organic land use, or other measures that ensure environmental sustainability, would offer promising alternative scenarios for long-term stability between economy and bird populations (Petit et al., 1995). In turn, the generation of knowledge about the functioning of natural environments in relict sites, especially in the Pampa region, is essential for establishing a baseline for future research and evaluation of management practices. Our results are a starting point for understanding the direct influence of land changes on richness and diversity of bird in this region of southern South America. We gained an insight into the consequences of vegetation replacement on the structure of bird assemblages and its meaning in terms of loss of regional biodiversity. The advance of the agricultural frontier is a global threat to grasslands. Our study provides information with a scientific basis and suggests priorities useful to guiding management of other grassland ecosystems.
ACKNOWLEDGEMENTS.-This work was financially supported by a CONICET fellowship to Pablo Brandolin and private contributions from DHF. For early comments on the manuscript, we thank two anonymous reviewers. We are grateful to the board of the Raquel and Pamela Schiele Foundation for allowing us to conduct this study. We thank Marcelo Frias, Ivan Grandoli and DHF staff for the cooperation in the logistics of field work. We are especially thankful to Ramiro Ramírez, Miguel Avalos, Julián Valetti and Javier Márquez for their collaboration during fieldwork.

\section{BIBLIOGRAPHY}

Agra, M., D. N. BilencA and Codesido, M. 2015. Responses of birds to planting of Lotus tenuis pasture in the Flooding Pampas, Argentina. Emu, 115: 270-276.

Azeria, E., IBARZÁbAl, J., HéBert, C., Boucher, J., IMBEAU, I. and SAVARD, J. L. 2011 . Differential response of bird functional traits to post-fire salvage logging in a boreal forest ecosystem. Acta Oecologica, 37: 220-229.

AzPiroz, A. B. and Blake, J. G. 2009. Avian assemblages in altered and natural grasslands in the northern Campos of Uruguay. Condor, 111: 21-35.

AzPiroz, A. B. and Blake, J. G. 2016. Associations of grassland birds with vegetation structure in the Northern Campos of Uruguay. Condor, 118: 12-23.

BibBy, C., Jones, M. and Marsden, S. 2000. Expedition field techniques bird surveys. BirdLife International. Cambridge.

BILENCA, D. and MiÑARO, F. 2004. Identificación de áreas valiosas de pastizal (AVPs) en las Pampa y Campos de Argentina, Uruguay y sur de Brasil. Fundación Vida Silvestre Argentina. Buenos Aires.

Brandolin, P. G., Ávalos, M. A. and De AngeLO, C. 2013. The impact of flood control on the loss of wetlands in Argentina. Aquatic Conservation: Marine and Freshwater Ecosystems, 23: 291-300.

Cantero, J. J. and León, R. J. C. 1999. The vegetation of saltmarshes in central Argentina. Beiträge zur Biologie der Pflanzen, 71: 203-242. 
CANTero, J. J. and León, R. J. C. 1999. The vegetation of saltmarshes in central Argentina.Beiträge zur Biologie der Pflanzen, 71: 203-242.

Cantero, J. J., Cantero, A. and Cisneros, J. M. 1996. La vegetación de los paisajes hidrohalomórficos del centro de la Argentina. Editorial de la Universidad Nacional de Río Cuarto. Río Cuarto.

Cantero, J. J., Nuñez, C. O., Amuchástegui, M. A. and Mulko, J. 2013. Cambios en el uso de la tierra y sus efectos sobre la vegetación del sur de la provincia de Córdoba. In, Giayetto et al. (eds): Bases conceptuales y metodológicas para el ordenamiento territorial en el medio rural, pp. 105-134. Libroclic Ediciones. Río Cuarto.

Carrascal, L. M. and Tellería, J. L. 1988. Relación entre avifauna y estructura de la vegetación en los medios agrícolas del norte de la Península Ibérica (País Vasco atlántico). Munibe, 40: 9-17.

Cerezo, A., Conde, M. C. and Poggio, L. 2001. Pasture area and landscape heterogeneity are key determinants of bird diversity in intensively managed farmland. Biodiversity Conservation, 20: 2649-2667.

Clarke, K and Gorley R. 2001. PRIMER v5: user manual/tutorial. Plymouth, UK.

Clarke, K. R. and WARWICK, R. M. 1994. Similarity-based testing for community pattern: the 2-way layout with no replication. Marine Biology, 118: 167-176.

Codesido, M., GonZÁLEZ-Fischer, C. and BILENCA, D. 2012. Agricultural land-use, avian nesting and rarity in the Pampa of central Argentina. Emu, 112: 46-54.

Codesido, M., GonZÁlez-Fischer, C. M. and BiLENCA, D. N. 2013. Landbird assemblages in different agricultural landscapes: a case study in the Pampa of Central Argentina. Condor, 115: 8-16.

Codesido, M., GonzÁlez-Fischer, C. M. and BILENCA, D. N. 2008. Asociaciones entre diferentes patrones de uso de la tierra y ensambles de aves en agroecosistemas de la región pampeana, Argentina. Ornitología Neotropical, 19: 575-585.

Cody, M. L. 1985. Habitat Selection in Birds. Academic Press, Inc.. Orlando, Florida.

CozZIAnI, N. and ZaLbA, S. 2009. Estructura de la vegetación y selección de hábitats reproduc- tivos en aves del pastizal pampeano. Ecología Austral, 19: 35-44.

Cueto, V. R., López de Casenave, J. and Marone, L. 2008. Neotropical austral migrant landbirds: population trends and habitat use in the central Monte desert, Argentina. Condor, 110: 70-79. Cueto, V. R., López de Casenave, J., Sagario, M. C. and Damonte, J. 2006. Relación avesvegetación: importancia de los algarrobales para la avifauna del desierto del monte. In, A. D. Brown, U. Martínez Ortiz, M. Acerbi and J. Corcuera (Eds): La Situación Ambiental Argentina 2005, pp. 234-239. Fundación Vida Silvestre Argentina. Buenos Aires.

De la Fuente, E .B. and SuÁrez, S. A. 2008. Problemas ambientales asociados a la actividad humana: la agricultura. Ecología Austral, 18: 239-252.

Devictor, V., and Jiguet, F. 2007. Community richness and stability in agricultural landscapes: the importance of surrounding habitats. Agric. Ecosyst. Environ., 120: 179-184.

Di Giácomo, A. S. and Krapovickas, S. 2005. Conserving the grassland important bird areas (IBAs) of southern South America: Argentina, Uruguay, Paraguay, and Brazil. USDA Forest Service Gen. Tech. Rep. PSW-GTR-191.

Di Giácomo, A. S. and López de Casenave, J. 2010. Use and importance of crop and field-margin habitats for birds in a neotropical agricultural ecosystem. Condor, 112: 283-293.

Dray, S. and Legendre, P. 2008. Testing the species traits-environment relationships: the fourth-corner problem revisited. Ecology, 89: 3400-3412.

Dufrene, M. and Legendre, P. 1997. Species assemblages and indicator species: the need for a flexible asymmetrical approach. Ecological Monographs, 67: 345-366.

FAHRIG, L., BAUdRY, J., Brotons, L., Burel, F. G., Crist, T. O. Fuller, R. J., Sirami, C., SiriwarDENA, G. M. and MARTin, J. L. 2010. Functional landscape heterogeneity and animal biodiversity in agricultural landscapes. Ecology Letters, doi: 10.1111/j.1461-0248.2010.01559.x

Filloy, J. and BellocQ, M. I. 2007. Patterns of bird abundance along the agricultural gradient of the Pampean region. Agriculture, Ecosystems and Environment, 120: 291-298. 
Filloy, J.,Zurita, G. A., Corbelli, J. M. and BelLOCQ, M. I. 2010. On the similarity among bird communities: Testing the influence of distance and land use. Acta Oecologica, 36: 333-338.

FLETCHER, R. J.JR. and KoFord, R. R. 2002. Habitat and landscape associations of breeding birds in native and restored grasslands. The Journal of Wildlife Management, 66: 1011-22.

Flynn, D. F. B., Gogol-Prokurat, M., Nogeire, T., Molinari, N., Trautman Richers, B., Lin, B.B., Simpson, N., Mayfield, M. M. and DECLERCK, F. 2009. Loss of functional diversity under land use intensification across multiple taxa. Ecology Letters, 12: 22-33.

Fuller, R. J., Gregory, R. D., Gibbons, D. W, Marchant, J. H., Wilson, J. D., Baillie, S. R. and CARTER, N. 1995. Population declines and range contractions among lowland farmland birds in Britain. Conservation Biology, 9: 14251441.

Gavier-Pizarro, G. I., Calamari, N. C., ThOMPSon, J. J., Canavelli, S. B., Solari, L. M., DeCarre, J., Goijman, A. P., Suárez, R. P., BERnARdos, J. N. and ZaCCAGNINI, M. E. 2012. Expansion and intensification of row crop agriculture in the Pampa and Espinal of Argentina can reduce ecosystem service provision by changing avian density. Agriculture, Ecosystems and Environment, 154: 44-55.

Gotelli, N. J. and EntSMinger, G .L. 2006. EcoSim: Null models software for ecology. Version 7. http://www.garyentsminger.com/ecosim/.

Graham, C. H. and BlaKe, J. G. 2001. Influence of patch- and landscape-level factors on bird assemblages in a fragmented tropical landscape. Ecological Applications, 11: 1709-1721.

Hanspach, J., Fischer, J., Stott, J. and Stagoll, K. 2011. Conservation management of eastern Australian farmland birds in relation to landscape gradients. J. Appl. Ecol., 48: 523-531.

Hendrickx, F., Maelfait, J. P., Desender, K., Aviron, S., BAiley, D., DiekotTer, T., Lens, L., Litra, J., Schweiger, O., Speelmans, M., VAndomme, V. and Bugter, R. 2009. Pervasive effects of dispersal limitation on within- and among-community species richness in agricultural landscapes. Global Ecol. Biogeogr., 18: 607-616.

IsACCH, J. P. and CARDONI, D. A. 2011. Different grazing strategies are necessary to conserve en- dangered grassland birds in short and tall salty grasslands of the Flooding Pampas. Condor, 113: 724-734.

IsACCH, J. P. and MartíneZ, M. M. 2001. Estacionalidad y relaciones con la estructura del hábitat de la comunidad de aves de pastizales de paja colorada (Paspalum quadrifarium) manejados con fuego en la provincia de Buenos Aires, Argentina. Ornitología Neotropical, 12: 345354.

IsACCH, J.P., Bo, M. S., Maceira, N. O., Demaría, M. R. and PeluC, S. 2003. Composition and seasonal changes of the bird community in the west pampa grasslands of Argentina. Journal of Field Ornithology, 74: 59-65.

Keith, T. H., Urban, D. L. and Milne, B. T. 1997. Detecting critical scales in fragmented landscapes. Conservation Ecology (online), 1: 4.

LACHER, T. E. JR., Douglas Slack, R., Coburn, L. M. and Goldstein, M. I. 1998. The role of agroecosystems in wildlife biodiversity. In, W.W. Collins, C.O. Qualset (Eds) Biodiversity in agroecosystems, pp. 151-169. CRC Press. Boca Raton, Florida.

Luck, G. W., Carter, A. and Smallbone, L. 2013. Changes in bird functional diversity across multiple land uses: interpretations of functional redundancy depend on functional group identity. PLOS ONE, 8: e63671.

MacArthur, R. H. and MacArthur, J. W. 1961. On bird species diversity. Ecology, 42: 594598.

Margules, C. and Pressey, R. 2000. Systematic conservation planning. Nature, 405: 243-253.

Mazerolle, M. J. and Villard, M. A. 1999. Patch characteristics and landscape context as predictors of species presence and abundance: a review. Ecoscience, 6: 117-124.

McCune, B. and Grace, J. B. 2002. Analysis of ecological communities. MjM Software Design. Gleneden Beach. Oregon.

Naugle, D. E., Johnson, R. R., Estey, M. E. and HigGins, K. F. 2001. A landscape approach to conserving wetland bird habitat in the Prairie Pothole Region of eastern South Dakota. Wetlands, 21: 1-17.

NEWTON, I. 2004. The recent declines of farmland bird populations in Britain: an appraisal of causal factors and conservation actions. Ibis, 146: 579-600. 
OESTERHELD, M. 2008. Impacto de la agricultura sobre los ecosistemas. Fundamentos ecológicos y problemas más relevantes. Ecología Austral, 18: 337-436.

ORMEROD, S. J. and WATKINSON, A. R. 2000. Editors' introduction: birds and agriculture. Journal of Applied Ecology, 37: 699-705.

Petchey, O. L., Evans, K. L., Fishburn, I. S. and GASTON, K. J. 2007.Low functional diversity and no redundancy in British avian assemblages. Journal of Animal Ecology, 76: 977-985.

Petit, D. R., Lynch, J. F., Hutto, E. L., Blake, J. G. and WAIDE, R. B. 1995. Habitat use and conservation in the neotropics. In, T. E. Martin and D.M. Finch (Eds) Ecology and management of neotropical migratory birds, pp. 145-200. Oxford University Press. New York.

Polis, G. A., POWER, M. E. and HuXEL, G. R. 2004. Food webs at the landscape level. University of Chicago Press. Chicago.

Quirós, R., Rennella, A., Boveri, M., Rosso, J. J. and SosNOVSKY,A. 2002. Factores que afectan la estructura y el funcionamiento de las lagunas pampeanas. Ecología Austral, 12: 175-185.

RENFREw, R .B. and RiBIC, C. A. 2001. Grassland birds associated with agricultural riparian practices in southwestern Wisconsin. Journal of Range Management, 54: 546-552.

Schawb, F. E., Simon, N. P. P. and Sinclair, A. R. E. 2006. Bird-vegetation relationships in southeastern British Columbia. Journal of Wildlife Management, 70: 189-97.

Shi, K., Maruyama, N., Koganezawa, M. and GAO, Z. X. 1999. Impacts of settled grazing on the bird communities in the Nantun Area, northern Inner Mongolia. Biosph Conserv, 2: 65-74.

Shutler, D., Mullie, A. and Clark, R. G. 2000. Bird communities of prairie uplands and wetlands in relation to farming practices in Saskatchewan. Conservation Biology, 14: 1441-1451.

Skowno, A. L. and Bond, W. J. 2003. Bird community composition in an actively managed savanna reserve, importance of vegetation structure and vegetation composition. Biodiversity and Conservation, 12: 2279-2294.

Soderstrom, B., Part, T. and Linnarsson, E. 2001. Grazing effects on between-year variation of farmland communities. Ecol.Appl., 11: 1141-1150.
Soriano, A., LeÓn, R. J. C., SAla, O. E., LaVado, R. S., Deregibus, V. A., Cahuepé, M. A., Caglia, O. A., Velázquez, C.A. and Lemcoff, J. H. 1991. Río de la Plata grasslands. In, R. T. Coupland, (Ed.): Ecosystems of the world 8A. Natural grasslands, pp. 367-407. Elsevier. New York.

Tews, J., Brose, U., Tielböroger, K., Wichmann, M. C., Schwager, M. and Jeltsch, F. 2004. Animal species diversity driven by habitat heterogeneity/diversity: the importance of keystone structures. Journal of Biogeography, 31: 79-92.

Vickery, J. A., Tallowin, J. R., Feber, R. E., Asteraki, E. J., Atkinson, P. W., Fuller, R. J. and Brown, V. K. 2001. The management of lowland neutral grassland in Britain: effects of agricultural practices on birds and their food resources. Journal of Applied Ecology, 38: 647-664.

Vickery, P. D., Tubaro, P. L., Cardos Da Silva, J. M., Peterjohn, B. G., Herkert, J. R. and Cavalcanti, R. B. 1999. Conservation of grassland birds in the western hemisphere. Studies in Avian Biology, 19: 2-26.

Vigglizzo, E., Frank, F. and Carreño, L. 2006. Situación Ambiental en las Ecorregiones Pampa y Campos y Malezales. In, A. D. Brown, U. MARTínez Ortiz, M. ACERBI and J. CORCUERA (Eds): La situación ambiental Argentina 2005, pp. 261-269. Fundación Vida Silvestre Argentina. Buenos Aires.

Wakeley, J. S., Guilfoyle, M. P., Antrobus, T. J., Fischer, R. A., BARROW, W. C. JR. and HAMEL, P. B. 2007. Ordination of breeding birds in relation to environmental gradients in three southeastern United States floodplain forests. Wetlands Ecology Management, 15: 417-439.

WEYLAND, F., BAUdRY, J. and GHERSA, C. M. 2014. Rolling Pampa agroecosystem: which landscape attributes are relevant for determining bird distributions? Revista Chilena de Historia Natural, 1: 1-12.

WhitTAKeR, R., WiLLIS, K. J. and FiELD, R. 2001. Scale and species richness: towards a general, hierarchical theory of species diversity. Journal of Biogeography, 28: 453-470.

With, K. A., King, A. W. and Jensen, W. E. 2008. Remaining large grasslands may not be suffi- 
cient to prevent grassland bird declines. Biological conservation, 141: 3152-3167.

Wretenberg, J., Part, T. and Berg, A. 2010. Changes in local species richness of farmland birds in relation to land-use changes and landscape structure. Biological Conservation, 143: 375-381.

Wu, C., Lin, Y. and Lin, S. 2011. A hybrid scheme for comparing the effects of bird diversity conservation approaches on landscape patterns and biodiversity in the Shangan subwatershed in Taiwan. J. Environ. Manage., 92: 1809-1820.

Yuan, Y., Zenga, G., Lianga, J., Li, X., Li, Z., Zhanga, Ch., Huanga, L., Lai, X., Lua, L., WU, H. and YUA, X. 2014. Effects of landscape structure, habitat and human disturbance on birds: A case study in East Dongting Lake wetland. Ecological Engineering, 67: 67-75.

\section{SuPPlEMENTARY ElECTRONIC MATERIAL}

Additional supporting information may be found in the on-line version of this article. See volume 63(2) on www.ardeola.org

Appendix 1: Systematic list and mean abundance per plant community of bird species recorded at Dos Hermanas Farm.

Received: 11 December 2015 Accepted: 07 April 2016

Editor: J. Sarasola 